Portland State University

PDXScholar

Fall 2020

\title{
Disney's Reign Over Independent Cinema: How Mega-Corporations Are Commercializing Creativity
}

Hannah Z. Dawson

Portland State University

Follow this and additional works at: https://pdxscholar.library.pdx.edu/honorstheses

Part of the Film and Media Studies Commons

Let us know how access to this document benefits you.

Recommended Citation

Dawson, Hannah Z., "Disney's Reign Over Independent Cinema: How Mega-Corporations Are Commercializing Creativity" (2020). University Honors Theses. Paper 941.

https://doi.org/10.15760/honors.964

This Thesis is brought to you for free and open access. It has been accepted for inclusion in University Honors Theses by an authorized administrator of PDXScholar. Please contact us if we can make this document more accessible: pdxscholar@pdx.edu. 
Disney’s Reign Over Independent Cinema:

How mega-corporations are commercializing creativity

\author{
by \\ Hannah Dawson \\ An undergraduate honors thesis submitted in partial fulfillment of the \\ requirements for the degree of \\ Bachelor of Arts \\ in \\ University Honors \\ and
}

Film Studies

Thesis Advisor

Dr. Kristin Hole

Portland State University 


\section{Abstract}

The Walt Disney Company is undoubtedly a monopoly in the media industry space. Their impressive acquisitions have expanded their portfolio to corner the market in nearly every genre. Most recently, the company has hired independent directors in hopes of re-invigorating and creating variety between multiple brands and franchises. But the directors' authoritative voices are lost under the Disney brand, which I argue overshadows independent autonomy and potentially envelopes the rest of the media market. Brandishing this massive media force, Disney (and its other subsidiary branches) promotes palatable, conservative leaning "family friendly" content that leads to a wider chance of profit. Despite a desired variety, the directors still work under a multi-billion-dollar business that expects to sell to the widest market available. This foregoes the power of independent cinema as a commanding voice and perpetuates a commercialized industry where artistry is lost to the promise of profit. To look at this problem, I will be in conversation with the discourse of media industry, media convergence and monopoly. This examination provides a detailed history of Disney's business model that has set the rest of Hollywood in financial submission. I will also look at two directorial collaborations (Black Panther (2018), Thor Ragnarök (2017)) and critical and scholarly discussions surrounding them, highlighting the censorship of topical issues, such as the Black Lives Matter movement, neocolonialism, masculinity, and indigenous directors. By using these specific analyses in reference to the media industry, I reflect upon the negative effects of the standardization under the Disney Monopoly. 


\section{General Background}

Disney owes it universal recognizability as a brand and a company to its exponential market growth over the past couple of decades, but this has come at a negative cost to the rest of Hollywood. Its lucrative strategies began in the eighties when the Reagan administration spearheaded steady deregulation of anti-trust laws including the Paramount case. This landmark decision of 1948 (studio era Hollywood) had formally restricted the studios' total monopoly but its repeals restored vertical integration as studios began re-buying exhibition locations. This meant a shift in attitude from an "iron fist wielded by the government" to "a façade of regulation...[in reality] supporting the film industry's bid for complete autonomy" (Holt 98). And theaters were not the only promise of profit. The economic philosophy welcomed "loosened restrictions on corporations" (Holt 99) and clued in on potential business mergers now that antitrust laws were waning. While Disney was never restricted by the Paramount decrees (having never owned theaters), the political atmosphere of money and laissez-faire economics (Holt 98) excited and spurred Disney's financial reinvention. In 1984, Michael Eisner, former head of Paramount (Wasko 12) commandeered the company and reassembled the crumbling "Magic Kingdom." Disney already owned outside markets (themes parks, merchandise, etc.) but the concentration on theme parks and real estate had left its films to the wayside and the potential for profit unrealized. Eisner steered the company in a new direction and reinvigorated the business model. Using the newly popularized and now legal strategies of "emphasized corporate partnerships, limited exposure in new investments, diversified expansion, and further developed...corporate synergy", (Wasko 12) Eisner skyrocketed the company into the new millennium. These choices were key in the changing Hollywood economy as well as the future of Disney. Deregulation had facilitated Hollywood's entrance into a global market where an 
emerging, more lucrative "internationalization of competition" (Wayne 89) had arrived. In the global hierarchy, Hollywood prevailed and the potential for growth outside America was plentiful (Wayne 90). They could saturate foreign media markets and create a one-sided culture flow that could be exported and imprint a glamorous western image. Mergers such as Sony Columbia Tri-Star and MCA/Universal strategized the marriage of "hardware and entertainment software in the media industries" (Holt 127) that eliminated foreign competition and birthed a mutual profit. This not only established companies' names in the global space as the dominant figures, but Eisner and others recognized these trends of multi-media corporate control returned staggering profits and helped grow their monopolies upon this new economic freedom and synergy.

Compared to past structures, the rise of the mega-corporation was a more advanced, international studio system. It could keep up in a fast-growing global economy where "a new plurality of units of capital operating in the marketplace" (Wayne 92) could be divested and vertically expand in the name of the company. These choices and the changing media landscape were foundational for Disney's future as it began to diversify and invest in new ventures and ancillary markets. The company's acquisition of Capital Cities in 1995 is and should be an exemplar of a hallmark merger. Its success displays the effective interplay of "globalization and deregulation [that] created tremendous... possibilities for media consolidation on a scale previously unimaginable" (Holt 115). Capital Cities owned ABC network and guaranteed Disney time for its own programming which could be slotted at primetime. The network's subsequent possession of ESPN also gave an expansive array of "regional syndication, international networks, radio, Internet, retail, print..." (Wasko 14) that promised lucrative additions to the growing house of mouse, not to mention previously established connections to foreign markets in 
Asia and Latin America (Wayne 95) that furthered a global network. This acquisition exemplified how corporations strategized based upon maximized financial gain and personal assets. It became the establishment as the "blueprint for most media conglomerates that were formed in its wake" (Holt 158) and foreshadowed the continuing success that is apparent today. This diversification positively grew over the years as other acquisitions were assessed and strategized to be a part of the Disney brand. In Disney's 1999 annual report, they remarked "ESPN reaches 77 million homes" and ABC's television stations reach " 24 percent of the nation's TV households" (Walt Disney Company 36). This astounding viewership translated to generated media network revenues of $\$ 7,512$ (in millions). Compare this to two years earlier in 1997 where the network was earning one million less $(\$ 6,522)$. This rapid growth presented Eisner with the results he wanted and established Disney's name as "one of the dominant players in U.S. media industry" (Wasko 248). Continuing into this past decade, Disney has maintained its approach and acquired other formidably promising brands.

The studio officially acquired Pixar Animation in January of 2006, Marvel Studios in December of 2009, Lucasfilms in October of 2012 and most recently, Fox Studios in March of 2019. These four subsidiaries had massive commercially and financially established content that attracted Disney to the potential for an expansive portfolio. I will focus on Marvel's acquisition later in the discussion, but it is critical to see how these feats should come as no surprise with Disney's business trajectory. The economic climate of the eighties and Eisner's transformation of the company established the momentum to continue this path to financial conquest. This history, (and still growing monopoly) has been a product of the birth of unyielding megacorporations as Disney continues to accrue multi-million dollar acquisitions and mergers. But today's situation expands beyond the reversal of the Paramount case. These mergers imply more 
than just television deals, merchandising, theme park attractions, and much more. They point to a cultural shift as Disney is quickly becoming the sole media giant that audiences and have become reliant and familiar with. Because Disney has become insatiable to obtain property, the company has slowly been eliminating all competition necessary for a working media economy. It not only affects the media industry but affects audiences and consumers media experiences. One must question how its dominance influences and perhaps restricts people's media experience negatively.

Multiple media scholars have lamented and remarked on the Disney brand as the Americana childhood full of "fantasy, imagination, and pleasure" (Wasko 23). As Janet Wasko points out, this image is glaringly "nurtured and controlled,... and effectively distributed to reach the hearts and minds of people all over the world" (253). Most people remember watching the classics as children and the (so-called) Disney magic that is easy to introduce at a young, impressionable age. It then morphs into the nostalgia of childhood innocence that adults so often recall. A Disney-oriented example: a viewer who is a big fan of Marvel watches the movies as a retreat to their childhood when they read the comic series. They also have a child who watches the animated comic series on Disney's children's programming (also planting these seeds). This viewer also is an avid collector of Marvel merchandise and own's licensed action figures, clothes, and other buys Disney merchandise targeted at children. To connect the two, the viewer subscribes to the Disney+ service so they can enjoy both. This fan's subconscious interaction with childhood nostalgia has been largely facilitated by Disney whose trademarked happiness is able to attract lifelong audience-ship. But this cheeriness fades into an over-sweetened façade that falls flatter over time. Despite the memories many grew up with, there is this clear "Disneyfication" that connotates a simplification or even a "sanitization and Americanization" 
(Bryman 12) of an object. Most of the analyses of "Disneyfication" have been around storylines (although it can be effective in other business strategies) that are given standardized treatments or culturally insensitive iterations through censorship and sanitation. This leaves them with a lackluster shine but still enough charm so that they may be "marketed with a raft of merchandise" (Bryman 12) and imprint in the memories of audiences for years to come. As I stated before, its breadth as a company must reach the widest base to maximize the biggest profits. Their reputation as a wholesome and family-oriented is a cornerstone not only to their company, but to the way they market themselves as a global force. Anything that strays or could be considered too radical for this image, is molded and made appropriate for the distinctive template and expectant audiences. This might sound exaggerated or dire, but this creates a restrictive environment beyond film.

In a study by an international political economy scholar, Alexandre Bohas discusses how a company like Disney “structures consumer-spectators' lives” (25) in a political and cultural economy, revealing the deeper implications of this commodified fantasy. In the table below, Bohas has divided what he refers to as Knowledge structures that represent a viewer's potential interactions with Disney. These four patterns represent the variables of "audiovisual media" and "parks and consumer products" (i.e. non-audiovisual modes) (Bohas 30). And understanding the size of the Disney empire, these two variables are open to a large scale of variance and overlap. He marks the traditional pattern as the sanctioned film experience that many grew up with (often the Disney classics). This implants that nostalgic association with childhood, often carrying Disney fans into adulthood. Bohas then remarks on perhaps the most relevant, multiproduct pattern. In the contemporary discussion, there is "an acute awareness and large knowledge of Disney goods" (Bohas 31) that circulate in nearly every conceivable market. It is practically 
inescapable in a consumer-driven economy where profit and selling are key. With the company's current holdings, it is hard to imagine the sheer scope of the "cross-consumption spiral on which the fate of Disney rests" (Bohas 32).

Table 1

The Knowledge and Consumption Patterns of Disney

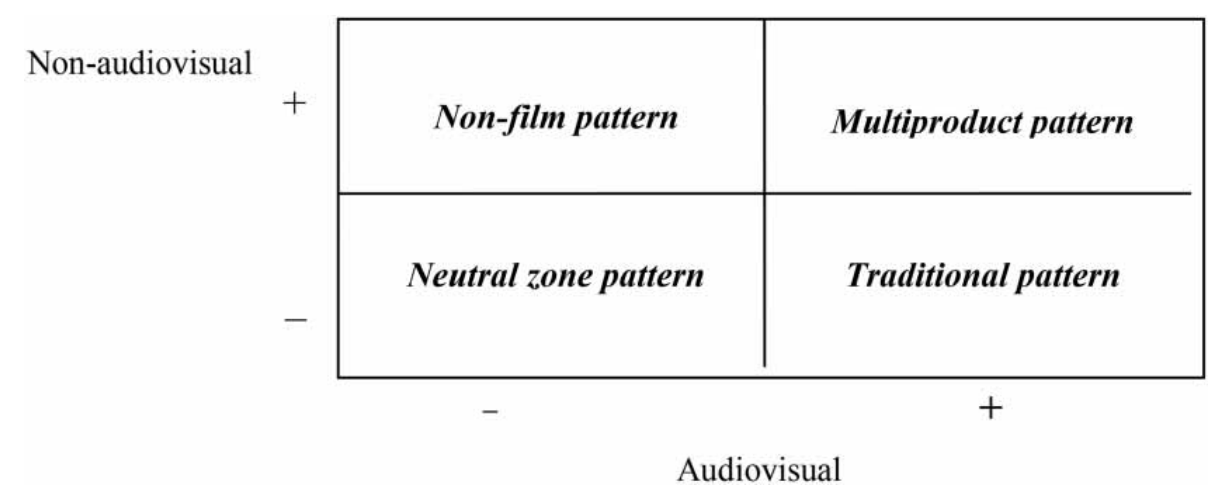

Source: Bohas, Alexandre. "Transnational Firms and the Knowledge Structure: The Case of the Walt Disney Company.” Global Society, vol. 29, no. 1, 2014, pp. 23-41.

Bohas' table is able to visualize the size of the company's magical synergy and conceptualize that Disney's power “comes from a material and ideational preponderance in global markets through the transnational scope of product and symbolic universes" (26). The company recognizes the buy-in through childhood magic and can spread and standardize their control through its multi-dimensional markets; offering products to keep the fantasy going past adolescence. It is no longer a fantastical feat for the House of Mouse but a haunting visual at the breadth of power that one company can wield. This saturation raises the question of what the state of the media economy. Audiences are quickly becoming reliant on Disney as the only platform and are subjected to a sterile, "Disneyfied" world whose dominance continually grows. The voices of other studios and creators are being drowned out or enveloped by these big 
companies who sell a "sacred aura [of]...childhood and innocence" (Wasko 23) that many never outgrow.

Disney in 90's Independent Cinema: Miramax and Their Own Disneyfication

Independent Cinema is not a new or recent discovery for Disney. Rather, independent film is a longstanding venture to create yet another branch under the monopoly. The nineties were a transitional period for independent cinema. It was riding off its renaissance of an "emergence and expansion of a number of independent distributors" (Perren 30), not to mention financial support from "institutional infrastructure[s] and a critical apparatus" such as the National Endowment for the Arts, Independent Feature Project and independent studios like Castle Hills Productions, Cinecom, and Horizon Films that championed these films (Tziousmakis 54). Yet, the eighties had welcomed Hollywood executives who sought opportunity in all facets of the media markets, suggesting that its success would not keep the independent scene in small, critical circles for long (Tzioumakis 56). In the executives' eyes, every market could prove possible financial gain. And the hallmark release of Steven Soderbergh's, Sex, Lies and Videotape (1989), confirmed this. The little indie film unprecedently pre-perfected a hybridized model of commercial and critical success that garnered the attention of major studios and distributors. Its instant success evidenced that "Indie cinema was going to be an...important part of the menu on offer" (Tziousmakis 57) to audiences. And executives were determined to try their hand at the independent game.

After the landmark, Sex, Lies, and Videotape, Disney bought the film's distributor, Miramax in 1993. Miramax had already made a name for itself by then as the Disney of Independent cinema. The Weinstein brothers selected films that could ride off "sex, violence, and controversy as sales strategies" (Perren 31) and took part in amplifying Videotape's success 
through such marketing. But Disney took the Weinstein's vision to transcend the art-house space, amplify it, and bring it to the Magic Kingdom where its name could be seen by millions. Several other studios followed suit in hopes of tapping into the indie market. Studios like Fox Searchlight and Sony Pictures Classics were among several created or taken under the monopolistic wing, and by proxy, into the commercial circuit. Unfortunately, what this meant was a deradicalization towards a commercial independent cinema. Indie films were previously marketed as high-brow media (which can be classist), but corporate blurred this distinction and instead transformed "mainstream media into its own competition and opposition"; seeking new ways to envelope content and streamline audiences to raise profit within "the sphere of cultural production" (Newman 17). The studios maintained a somewhat laissez-faire production environment. But the obscurity of unknown actors and small budgets was no longer accepted. If these projected profits were going back to Disney, Sony, etc, these films needed to expand their ability to build "further opportunities for synergies between themselves and the conglomerates' other established media branches" (Tziousmakis 58). Studios began to commercialize or "Diseny-fy" the increasingly recognizable indie by tailoring it to wider audiences. Tactics like attractive star power and sell-able directors reformulated and relabeled the indie as mid-range "high-brow" for the masses. Plots lacked the former underground cult status but clung onto enough complexity for them to be considered non-mainstream. Films like Tarantino's Pulp Fiction (1994) and Van Sant's Good Will Hunting (1997) exemplified that "aesthetically, their independence is questionable" and underscored "the extent to which "independence" (or its hip offspring, "indie") served as a discursive tool employed by the press and the industry" (Perren 37). 
As seen in the financial return tables below, independent studios became inherently tied to larger corporate structures. Distributors like Miramax and Sony Pictures Classics were characterized as singular companies but really served to make more money under their respective monopolies. Tziousmakis (2013) builds off his data as evidence in argument for the independent as the commercial. He argues that independent cinema in one way or another has been "firmly [established] within the fold of a small number of global conglomerates that control entertainment and made it into just another market segment to serve" (64).

Table 2. Top 15 Distributors' share of the US theatrical market

\begin{tabular}{|l|l|l|l|l|}
\hline & Company & \# of films & Box office gross & Market share \\
\hline 1 & Walt Disney Pictures & 38 & $\$ 1,010,877,397$ & $19.10 \%$ \\
\hline 2 & Warner Bros. & 29 & $\$ 865,542,029$ & $16.36 \%$ \\
\hline 3 & Sony Pictures & 31 & $\$ 680,228,916$ & $12.86 \%$ \\
\hline 4 & Universal & 21 & $\$ 665,930,895$ & $12.59 \%$ \\
\hline 5 & Paramount Pictures & 21 & $\$ 529,540,293$ & $10.01 \%$ \\
\hline 6 & 20th Century Fox & 15 & $\$ 410,286,239$ & $7.75 \%$ \\
\hline 7 & MGM & 18 & $\$ 331,009,793$ & $6.26 \%$ \\
\hline 8 & New Line & 15 & $\$ 329,282,831$ & $6.22 \%$ \\
\hline 9 & Miramax & 36 & $\$ 180,696,655$ & $3.41 \%$ \\
\hline 10 & Savoy & 9 & $\$ 65,063,313$ & $1.23 \%$ \\
\hline 11 & MacGillivray Freeman Films & 1 & $\$ 64,800,000$ & $1.22 \%$ \\
\hline 12 & Gramercy & 15 & $\$ 58,068,741$ & $1.10 \%$ \\
\hline 13 & Sony Pictures Classics & 14 & $\$ 20,809,288$ & $.39 \%$ \\
\hline 14 & Goldwyn Entertainment & 8 & $\$ 20,587,934$ & $.39 \%$ \\
\hline 15 & Fine Line & 11 & $\$ 14,333,441$ & $.27 \%$ \\
\hline & & & Total & $99.16 \%$ \\
\hline
\end{tabular}

Source: Tzioumakis, Yannis. "American Independent Cinema in the Age of Convergence", Revue française d'études américaines, vol. 136, no. 2, 2013, pp. 52-66

Table 3. US Theatrical market in 1995 by type of distribution company

\begin{tabular}{|l|l|}
\hline Type of Company & $\begin{array}{l}\text { Market } \\
\text { Share }\end{array}$ \\
\hline 7 diversified or conglomerated Hollywood majors & $84.93 \%$ \\
\hline $\begin{array}{l}2 \text { "major independents" w/corporate ties to the conglomerates (New Line and } \\
\text { Cinema) }\end{array}$ & $9.63 \%$ \\
\hline 3 studio specialty divisions (Gramercy, SPC, and Fine Line Features) & $1.76 \%$ \\
\hline
\end{tabular}




\begin{tabular}{|l|l|}
\hline US Theatrical market share controlled by conglomerates & $\mathbf{9 6 . 3 2 \%}$ \\
\hline 1 distributor specializing in large format films (MacGillivray Freeman Films) & $1.22 \%$ \\
\hline $\begin{array}{l}\text { US Theatrical market share controlled by large format and conglomerate } \\
\text { distributors }\end{array}$ & $\mathbf{9 7 . 5 4 \%}$ \\
\hline 2 most commercially successful independent distributors & $1.62 \%$ \\
\hline Top 15 distributors & $99.16 \%$ \\
\hline Remaining independent distributors & $0.84 \%$ \\
\hline
\end{tabular}

Source: Tzioumakis, Yannis. "American Independent Cinema in the Age of Convergence", Revue française d'études américaines, vol. 136, no. 2, 2013, pp. 52-66

Disney relinquished Miramax in 2010. Former CEO, Bob Iger claimed "Our current strategy for Walt Disney Studios is to focus on the development of great motion pictures under the Disney, Pixar and Marvel brands" (NYT.com). But that does not mean Disney has given up on the indie film altogether or its corporate business strategies. These ramifications are bolder than before as major studios continue to shift and integrate independent cinema (and other genres) into the mainstream to give them the same commercial treatment. Iger's statement suggests these tactics may certainly be employed under the other brands that have since financially exploded. But this practice restricts competition, and any new acquisition is automatically a proprietary for commercial profit. The result is the shutting out of marginal voices that have financial and creative potential in a market dominated by Disney.

\section{Marvel: A Specific Case of Commercial Control}

For the purposes of this thesis, I will only be discussing the theatrical Marvel Universe since Marvel television undergoes more discussion between deals and spin-offs. Marvel's acquisition under Disney in 2009 proved an even bigger return than ABC. In the contemporary market, Marvel has returned a gross $\$ 17$ billion to its parent company (HBR) that secures Disney in its continued market dominance. This specific merger was the origin story of Disney's twentyfirst century growth and exemplifies their specific synergy in the market. 
Starting as a print comic book company, Marvel specialized in the superhero genre and created a roster of heroes and villains. But its impending bankruptcy in the late 90's signaled that the company needed to look for other profitable outlets, ultimately settling on the movie making route in Hollywood. Marvel understood the massive financial potential of their films because they acknowledged "a transmedia storytelling strategy that maximize[d] industrial systems geared to convergence” (Flanagan, et. al 42). Cinema has transformed into a space where superhero movies have now become a cultural staple and the various external markets of videogames, merchandise, etc. multiply these profitable avenues. In its days as an independent studio, Marvel managed moderate-to-significant success at the box office with hits like the Spiderman trilogy (Sam Raimi, 2002-2007) and X-men (Brian Singer, 2000) that proved its viability. It was with this newfound confidence that Marvel took on and released Iron Man in 2008. This production hedged its bets on the ability for an independent comic company to produce a blockbuster (Johnson 1). Its past victories legitimized the expansion of Marvel as a player in Hollywood and Iron Man's apparent financial and critical success proved its ability to produce "cultures of cinema...reimagined" (Johnson 3). Upon its release, New York Times critic, A.O. Scott heralded the movie a refreshingly "unusual good superhero movie" that thrust audiences into a "world that crackles and with character and incident." Scott and other critics attributed the film's success to the combination of Favreau's tonal direction and Downey Jr.'s charming performance. The film was able to be original within a constrained genre known for its action and overblown effects. Roger Ebert's claim that it surpassed the "reality of illusion" elevated Marvel as the comic studio and cemented it in the minds of audiences as well as executives. 
Iron Man had clearly proved Marvel's worth and Disney took quick notice. Scott's opening line of the review "The world at the moment does not suffer from a shortage of superhero movies" foreshadowed the genesis the studio now had in their hands. Marvel Studios had independently started as a "transmedia producer" (Flanagan et al. 42) and it was quickly issued an offer of $\$ 4$ billion that won over the superhero studio. It was considered an overpriced and perhaps an overly zealous purchase at the time, but Iger knew the possibilities of advancing Marvel onto an even bigger trajectory of success. Global consultant, Joseph Calandro Jr., studies the assets of the purchase that has garnered so much money, but most importantly, the impressive Marvel portfolio of superheroes and extensive comic book collections (Calandro Jr. 2). Its bounty of material promised a plethora of movies and production potential that Iger foresaw as "opportunities of unknown market space" (Calandro Jr. 2). Iron Man had made a sizeable profit at its release, $\$ 585.3$ million to be exact, but the subsequent twenty releases since then have proved that Marvel's content is yet to run dry. The studio's longevity seems infinite with its ever-flowing source material and knack for "broad-based story-line market opportunities" (Calandro 4). And the compounding value from the comics' film translations has since returned millions in profit.

This leads to the more nuanced discussion behind the creation of the highly lucrative Marvel Cinematic Universe. And "true to that promise, Marvel announced after the Iron Man opening its intention to organize long-term film development around an Avengers film" (Johnson 6). Based on the interwoven comic stories, Marvel had a prefabricated franchise on their hands. Beginning with Favreau's smash hit, each film would narratively inform the others and continue to build upon this assembly of superheroes. It was an ambitious task story-wise, but it also banked on the audience's willingness to keep flocking to theaters for the next installment of this 


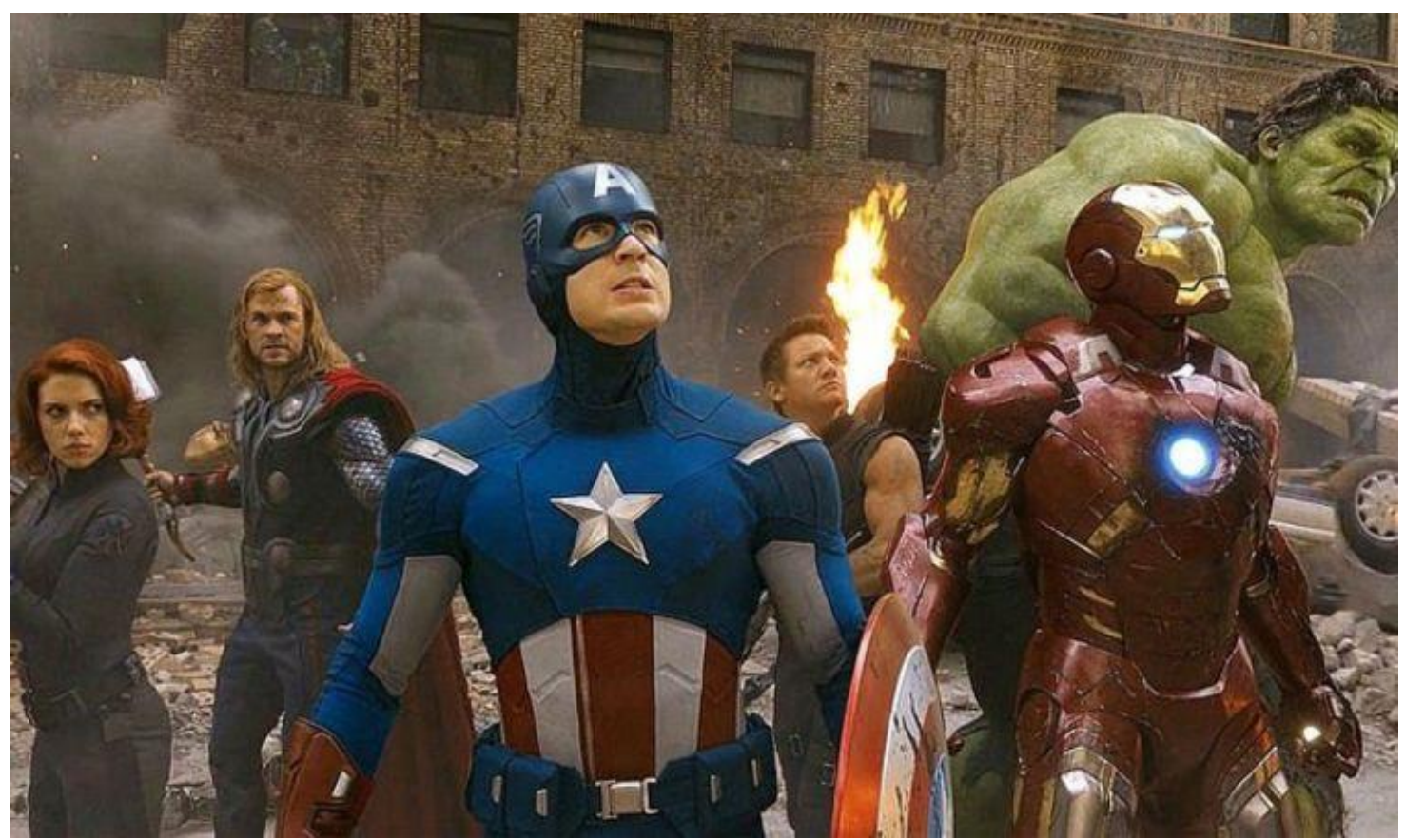

Fig. 1 Walt Disney Pictures. “Avengers Assemble.” Slant. 18, May 2012

heroic adventure. And President of Marvel, Kevin Feige assured fans and executives of this plan. In an interview with NPR, he reveres, "[the] notion of a shared, ongoing, fictional narrative...inhabiting the same universe...that hadn't been possible in movies" (npr.org). Each film would build the anticipation (and encourage frequent moviegoing) and finally reward fans with the savored reunion. The first assembly of the Avengers in 2012 garnered an astounding $\$ 1.519$ billion that clearly resonated with comic film fans and their wallets. At that point, four of the six (Iron Man, Captain America, Hulk, and Thor) had already released standalone origin narratives that laid the filmic foundation and set it up for the reunion. Roger Ebert described the films as the "Westminster Dog Show of Superheroes" that paraded its prized heroes around the screen, but it "provides its fans with exactly what they desire" (Ebert). Marvel was building spectacle for fans to marvel at quite literally. The image from The Avengers (2012) delivers the ultimate comic fantasy as the swelling music in the scene cries like a battle anthem as the Avengers prepare for the climactic war against the alien invaders.

In its first three years, "Marvel-Disney,...has maximized the value of each movie that it has made...as an integral part of the overall “ "Marvel Cinematic Universe' ” (Calandro Jr. 3) 
with twenty-three movies to date since the prodigal Tony Stark. Many have commented on the “super" formula behind the movies' success and "first ten years" foreshadows below Marvel will endure long past this. The superhero genre can easily wear out its reliance on CGI-action sequences and the hero's triumph against evil, so Marvel has undertaken some alterations to the formula. An evaluation by the Harvard Business Review boils it down to a few simple, yet powerful strategies, most importantly hiring offbeat or lesser known directors. In the same NPR interview, Kevin Feige described the directorial hiring process: "what we need the filmmakers to do ... [is] take those groups of artists who know how to do this amazing spectacle on a big canvas, and bring a very personal touch to it, and bring a unique vision to it." The strategy is not necessarily negative, it gives a great opportunity to and wider exposure for these directors, but I do not agree with the way that their visions are often scrubbed or warped by the corporate parameters of Marvel (despite Feige's description). Directors like John Favreau, James Gunn, Taika Waititi, and Jon Watts were versed in "Shakespeare, horror, espionage, and comedy" (HBR) and given supposedly free reign similar to the commercial independent scene of the '90's. But now with the expectation that the story must sustain its own weight as a standalone and more importantly, that it must fit narratively and thematically within the mega-franchise.

Marvel makes their money through the purposeful interconnection between films and the MCU is paramount. The Guardians trilogy may have taken on the space genre while Spiderman returned to a John Hughes-esque adolescence story, and Ant-Man was a heist adventure (HBR), but they foremost had a duty to the Marvel Cinematic Universe. While individual films keep the cinematic monotony at bay, they must also keep avid fans excited for the subsequent installments and battles to come. Marvel understands the need to create 
something further than endless explosions, but their directors also critically understand their position on the corporate ladder.

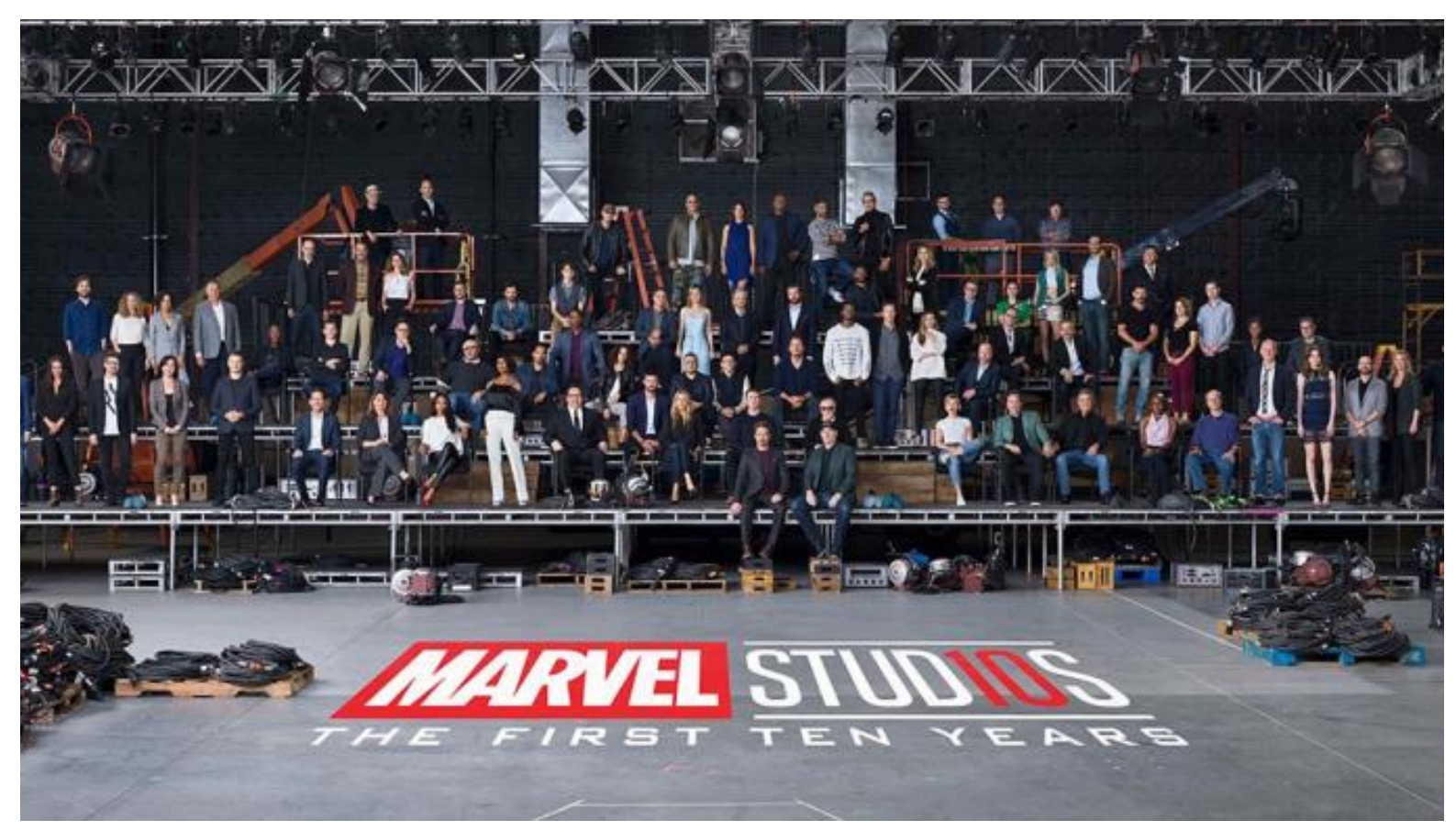

Fig. 2 Grob, Marco. "Marvel Studios: the first ten years." Variety. 8, February 2018

Feige later remarked in an interview with Variety, "new filmmakers coming in, inherently understand the notion of the shared sandbox more than the initial filmmakers did, because the sandbox didn't exist. In certain ways, that dialogue has become easier to have with a broader audience because we have such a library now of characters to pull from." The sandbox has become bigger, bigger in expected returns, profits, and the need to constantly find another hero story. The director foremost must understand, "The franchise narrative is a delicate balancing act highly affected by the number of active production entities involved in the filmmaking process, and their interests in the property" (Owczarski 677). Yes, giving creative variety to the Marvel Universe is a smart move and enriches the conventions of the superhero genre. But it is made clear that artistic license is not the main goal as Disney has always sought for the highest profits. And Marvel ever remains a subsidiary of Disney who dominates the global market and maintains 
careful authority over their divisions. Their creative choices are majoritively influenced by the goal of an ever-growing market return. Franchising through the Marvel formula (specifically the director) is a device used to make their films attractive standouts in competition with the rest of the CGI clutter. They are taking independent filmmakers into the corporate fold to give their films flair but also expecting large box office returns.

Table 4 - Box Office History for Marvel Cinematic Universe Movies

\begin{tabular}{|c|c|c|c|c|c|}
\hline $\begin{array}{l}\text { Release } \\
\text { date }\end{array}$ & Title & $\begin{array}{l}\text { Production } \\
\text { budget }\end{array}$ & $\begin{array}{l}\text { Opening } \\
\text { weekend }\end{array}$ & $\begin{array}{l}\text { Domestic box } \\
\text { office }\end{array}$ & $\begin{array}{l}\text { Worldwide box } \\
\text { office }\end{array}$ \\
\hline $\begin{array}{l}\text { Jul 6, } \\
2018\end{array}$ & $\begin{array}{l}\text { Ant-Man and } \\
\text { the Wasp }\end{array}$ & $\$ 1,30,000,000$ & $\$ 75,812,205$ & $\$ 216,648,740$ & $\$ 623,148,740$ \\
\hline $\begin{array}{l}\text { Apr } \\
27, \\
2018\end{array}$ & $\begin{array}{l}\text { Avengers: } \\
\text { Infinity War }\end{array}$ & $\$ 300,000,000$ & $\$ 257,698,183$ & $\$ 678,815,482$ & $\$ 2,048,803,724$ \\
\hline $\begin{array}{l}\text { Feb } \\
16, \\
2018\end{array}$ & $\begin{array}{l}\text { Black } \\
\text { Panther }\end{array}$ & $\$ 200,000,000$ & $\$ 202,003,951$ & $\$ 700,059,566$ & $\$ 1,348,359,566$ \\
\hline $\begin{array}{l}\text { Nov 3, } \\
2017\end{array}$ & $\begin{array}{l}\text { Thor: } \\
\text { Ragnarok }\end{array}$ & $\$ 180,000,000$ & $\$ 122,744,989$ & $\$ 315,058,289$ & $\$ 846,980,024$ \\
\hline $\begin{array}{l}\text { Jul 7, } \\
2017\end{array}$ & $\begin{array}{l}\text { Spider-Man: } \\
\text { Homecoming }\end{array}$ & $\$ 175,000,000$ & $\$ 117,027,503$ & $\$ 334,201,140$ & $\$ 880,166,350$ \\
\hline $\begin{array}{l}\text { May 5, } \\
2017\end{array}$ & $\begin{array}{l}\text { Guardians of } \\
\text { the Galaxy } \\
\text { Vol } 2\end{array}$ & $\$ 200,000,000$ & $\$ 146,510,104$ & $\$ 389,813,101$ & $\$ 862,317,259$ \\
\hline $\begin{array}{l}\text { Nov 4, } \\
2016\end{array}$ & $\begin{array}{l}\text { Doctor } \\
\text { Strange }\end{array}$ & $\$ 165,000,000$ & $\$ 85,058,311$ & $\$ 232,641,920$ & $\$ 676,405,470$ \\
\hline $\begin{array}{l}\text { May 6, } \\
2016\end{array}$ & $\begin{array}{l}\text { Captain } \\
\text { America: Civ } \\
\text { il War }\end{array}$ & $\$ 250,000,000$ & $\$ 179,139,142$ & $\$ 408,084,349$ & $\$ 1,140,075,017$ \\
\hline $\begin{array}{l}\text { Jul 17, } \\
2015\end{array}$ & Ant-Man & $\$ 130,000,000$ & $\$ 57,225,526$ & $\$ 180,202,163$ & $\$ 518,858,449$ \\
\hline $\begin{array}{l}\text { May 1, } \\
2015\end{array}$ & $\begin{array}{l}\text { Avengers: } \\
\text { Age of } \\
\text { Ultron }\end{array}$ & $\$ 330,600,000$ & $\$ 191,271,109$ & $\$ 459,005,868$ & $\$ 1,403,013,963$ \\
\hline $\begin{array}{l}\text { Aug 1, } \\
2014\end{array}$ & $\begin{array}{l}\text { Guardians of } \\
\text { the Galaxy }\end{array}$ & $\$ 170,000,000$ & $\$ 94,320,883$ & $\$ 333,172,112$ & $\$ 770,867,516$ \\
\hline $\begin{array}{l}\text { Apr 4, } \\
2014\end{array}$ & $\begin{array}{l}\text { Captain } \\
\text { America: } \\
\text { The } \\
\text { Winter... }\end{array}$ & $\$ 170,000,000$ & $\$ 95,023,721$ & $\$ 259,746,958$ & $\$ 714,401,889$ \\
\hline
\end{tabular}




\begin{tabular}{|c|c|c|c|c|c|}
\hline $\begin{array}{l}\text { Nov 8, } \\
2013\end{array}$ & $\begin{array}{l}\text { Thor: The } \\
\text { Dark World }\end{array}$ & $\$ 150,000,000$ & $\$ 85,737,841$ & $\$ 206,362,140$ & $\$ 644,602,516$ \\
\hline $\begin{array}{l}\text { May 3, } \\
2013\end{array}$ & Iron Man 3 & $\$ 200,000,000$ & $\$ 174,144,585$ & $\$ 408,992,272$ & $\$ 1,215,392,272$ \\
\hline $\begin{array}{l}\text { May 4, } \\
2012\end{array}$ & $\begin{array}{l}\text { The } \\
\text { Avengers }\end{array}$ & $\$ 225,000,000$ & $\$ 207,438,708$ & $\$ 623,279,547$ & $\$ 1,517,935,897$ \\
\hline $\begin{array}{l}\text { Jul 22, } \\
2011\end{array}$ & $\begin{array}{l}\text { Captain } \\
\text { America: } \\
\text { The First ... }\end{array}$ & $\$ 140,000,000$ & $\$ 65,058,524$ & $\$ 176,654,505$ & $\$ 370,569,776$ \\
\hline $\begin{array}{l}\text { May 6, } \\
2011\end{array}$ & Thor & $\$ 150,000,000$ & $\$ 65,723,338$ & $\$ 181,030,624$ & $\$ 449,326,618$ \\
\hline $\begin{array}{l}\text { May 7, } \\
2010\end{array}$ & Iron Man 2 & $\$ 170,000,000$ & $\$ 128,122,480$ & $\$ 312,433,331$ & $\$ 621,156,389$ \\
\hline $\begin{array}{l}\text { Jun 13, } \\
2008\end{array}$ & $\begin{array}{l}\text { The } \\
\text { Incredible } \\
\text { Hulk }\end{array}$ & $\$ 137,500,000$ & $\$ 55,414,050$ & $\$ 134,806,913$ & $\$ 265,573,859$ \\
\hline $\begin{array}{l}\text { May 2, } \\
2008\end{array}$ & Iron Man & $\$ 186,000,000$ & $\$ 102,118,668$ & $\$ 318,604,126$ & $\$ 585,171,547$ \\
\hline Total & 20 & $\$ 3,911,100,00$ & $\$ 2,507,593,81$ & $\$ 6,869,613,16$ & $\$ 17,503,126,81$ \\
\hline $\begin{array}{l}\text { Total } \\
\text { since } \\
2009 \\
\end{array}$ & 18 & $\$ 3,435,600,00$ & $\$ 2,350,061,13$ & $\$ 6,416,202,17$ & $\$ 16,652,381,45$ \\
\hline $\begin{array}{l}\text { Ave. } \\
\text { since } \\
2009 \\
\end{array}$ & & $\$ 190,866,667$ & $\$ 130,558,950$ & $\$ 356,455,673$ & $\$ 925,132,302$ \\
\hline
\end{tabular}

Sources: Calandro, Jr., J. (2019), "M\&A deal-making: Disney, Marvel and the value of "hidden assets"", Strategy and Leadership, Vol. 47 No. 3, pp. 34-39.

Notes: Avengers Endgame not released when table was made, but grossed another $\$ 2$ billion

Anthony and Joe Russo, who directed two of the three mega-reunion films understand this the most. Coming from a background in television and low-budget filmmaking, they were thrust into the Marvel Universe and charged with the mega-installments, Avengers: Infinity War (2018) and Avengers: Endgame (2019) that grossed a combined \$5 billion (not to mention two other Marvel installments). In an interview with the DGA, Joe Russo gushed "We've always appreciated experimental filmmaking." But he also inherently understands that Marvel's directors must always "keep surprising the audience tonally, or they're going to get ahead of 
you." As stated before, the commercial overshadows the creative and the independent scene is being enveloped by the safe, financially reliable parameters of corporate moviemaking. These new and "daring" risks to the Marvel Cinematic Universe are ventured only to please audiences and grow the franchise. Feige has since announced dozens more Marvel productions slated in the coming years, but I want to investigate this formula by focusing on two compelling case studies.

Out of all the newcomers to the Marvel directorial Universe, Taika Waititi and Ryan Coogler have been described as the most dynamic and interesting choices. Their films, Black Panther (2018) and Thor: Ragnarök (2017) have garnered extensive discussion about their thematic approaches. These films illustrate the rather unbalanced dynamic of the commercial and creative in the Disney/Marvel corporation.

\section{Black Panther}

The highly anticipated 2018 release of Ryan Coogler's Black Panther celebrated the first black superhero to grace the screen. With a predominantly black cast and crew and a plot set in an African kingdom, it garnered its due merits and quickly made $\$ 1.34$ billion at the box office. Here, I examine the critiques that followed the film, in order to address the possible lack of exploration of or lost potential for a more socially charged message. First, I will discuss Coogler's directorial past and his powerful thematic tone, which is muddled by Disney's Marvel formula and then I will address critiques of the film's tribalistic and reductionist approach.

Coogler's debut film, Fruitvale Station (2013) recounts the true story of the murder of Oscar Grant, a 22-year-old African American man, who was shot by a police officer at a train station in Oakland, California. It received praise for its humanistic and layered portrayal of Grant rather than succumbing to what A.O. Scott described as the tendency to "turn a man into a symbol...flattened out by the...psychopathology of everyday American life" (NYT.com). This is 
also Robin Boylorn's argument in the article, "From Boys to Men: Hip-Hop, Hood Films, and the Performance of Contemporary Black Masculinity” (2017). Boylorn analyzes Fruitvale Station and other films to explore changing representations of black masculinity through the hiphop film genre (aka New Black Realism). In Michael B. Jordan's portrayal of Oscar Grant, there is a change, a progression as the main character reveals layers of internalized moral struggle. Instead of an emotionally hardened or constantly angry character, he changes his behavior with different people to assume the correct masculinity for that relationship and reveals a nuanced and realistically complicated character. "However, when Oscar dies the possibilities of progressive masculinity die with him. We are left to wrestle with the ways his black maleness and the assumptions connected to it led to his death...the focus shifts...to how to deconstruct systemic racism and paranoia about black men" (Boylorn 150). It is no longer just an intimate look at one man's life, but “exposes black masculinity as a social phenomenon...” (Boylorn 158). Coogler's film is again not a symbol of a movement or trope, but a progressively honest look at black men compared to its predecessors. New Black Realism stemmed from the violent realities of innercity communities and allowed black (mostly male) voices to authentically present complex lived experiences. Andrew T. Burt in his essay, “A New Jack Cop in a New Jack City: New Black Realism and Conceptions of the "Bad Man"" notes the reformation and understanding of a bad man from historical notions of "African-American folklore" (934) as those who claimed autonomy and rose up against racial and social oppression. The interpretation of "bad" evolved from a fear of the rebellious who made "life more unbearable for blacks trying to live an everyday existence under an oppressive system" (934) to a positive connotation of "portraying empowered black characters... adapting to changing community climates" (935). Oscar is not a perfect protagonist like in a Marvel movie; he, again, is ever-evolving in an unstable 
environment, whether it be supporting his family or flashbacks to his time in prison. It explores a complicated life rather than its characters being "presented as pathologies or unfortunate stereotypes" (Boylorn 148) and allows an "arena for a re-evaluation of the 'bad' character" (Burt 937). One understands the misdeeds of Oscar's life but Coogler also makes the point that his life is not an exceptional experience. The film gives power and voice to the reality in these underprivileged areas.

But Boylorn also highlights the sad reality of the "maturation of black male characters and their [shortened] survival" (148). Emphasizing the struggle of survival, the ending of Fruitvale Station and other films points to death (or other tragic events) as the filmic ultimatum. The men are left with no other choice and question the potential of their realities. Boylorn references Sheril Antonio's point that “black filmic enterprise is an instrument for critique, not just of representations but of omissions... [where] [e]ach film requires a black man to die in order for progressive black masculinity to be possible" (Boylorn 149). Death cuts off all possibility for said character and instead does a disservice to this progress. It silences the voice then and there and states that death is the status quo. New Black Realism is powerful because it "prioritizes the black male as the voice of change" (Burt 936), but it cannot create an open discussion if that voice continues to be silenced. Fruitvale Station is based on a true event that Coogler portrayed complexly; but Black Panther, despite its fictional status, had the potential to redeem both the hero and the villain as real characters.

Michael B. Jordan, who is a frequent collaborator with Coogler, signed onto Black Panther as Erik Killmonger, the wronged villain who is killed in the grand finale. His story is also rooted in Oakland, California (Coogler's birthplace). The film flashes back to urban America to set up the events of the movie even before visiting the Afrofuturistic, fabled 
Wakanda. Killmonger's father, N'Jobu, is a Wakandan spy who is killed by his brother for abetting the theft and international use of their prized resource, vibranium. N'Jobu's motives are based in "survival in the dangerous circumstances of...poverty, depravity, violence, and hopelessness therein" (Boylorn 148) that he has witnessed during his stay in America. He pleads before his death, referring to black Americans, "their leaders have been assassinated. Communities flooded with drugs and weapons. They are overly policed and incarcerated." This reflects (and retreats back to Coogler's past) environments of the ghetto as depicted in the hiphop films referenced earlier and gives a legitimate and empathetic motive for the so-called villains who want to use vibranium to fuel a better world. While the scene could be criticized for reproducing the "conspicuous violence of hood narratives" representing "black masculinity as invulnerable, dangerous, and endangered, within the limited confines of the(ir) ghetto" (Boylorn 148), it gestures to the real-life disparity and injustice experienced in black communities all over the world. When young Killmonger asks for "the story of home," he is told this grand mythology of a land (Wakanda) not ravaged but that has triumphed and endured. The pulsating vibranium acts like a vein structure that gives the Afrofuturistic Wakanda its power and life force. The themes of Afrofuturism champion "literature, arts, music, music videos, fashion design, films and television programmes through a black lens" and center "black protagonists who wield power through advanced science and technology" (Karam 5). Wakanda is the center of this excellence that only a few are privileged to experience as a kingdom (mostly) without the terrors of war, famine, and other ills. When it returns to present day, we are informed that Killmonger, growing up in Oakland rather than Wakanda, has had to build his own future from nothing and one cannot help sympathize with his plight. His homeland cast him aside and instead he trained in the military and went to MIT all in the name of vengeance. Past Marvel villains are statically 
developed as the foil to the heroic protagonist, but Jordan's character is layered, and his revenge is a product of grief and injustice.

In The Atlantic, Adam Serwer dissects Killmongers' twisted motives from peace to the political hegemony that he eventually wins. Erik Killmonger ideologically seeks the "global liberation of black people. But that is not truly his goal." His coup over Wakanda ushers in a new era and militarizes the country in an act of revenge and domination. He wants Wakanda to fall and be reborn in his image, and engages in "fratricidal violence... a Black Panther against the Black Panther... [and] is blinded by his pain to the evil of his own methods" (Serwer). Despite Black Panther's own father who also committed fratricidal violence. He and his father were banished and isolated from their own nation and cut from a lineage he associates with retribution and spite. Coogler is fleshing out deep-rooted suffering linked to "collective, cultural and historical traumas. Of imperialism, and violence, of capitalism, and recolinisation" (Karam 6) that are morally lost in Black Panther's eyes. But they are presented as justification for the villain that has become an anti-villain to many fans. The concept of the bad man and his motives are ever-evolving. Burt notes "the fluidity of expectations for the male body... while showing how intrinsic a realistic, nuanced expectation of masculinity is to community change" (937). Killmonger's pursuit of justice is openly based on the oppression of black men (not a specific context) but proves this universality of trauma and abuse that needs liberation. When Killmonger visits a British museum, he points to the colonialist irony as well as the curator's condescension against him. He argues, asserting, "Where do you think your ancestors got these? You think they paid a fair price? Or did they take it like they took everything else?" This is the history that most are familiar with and as triumphant as Afrofuturism is portrayed, it is again a privileged experience that conversely Killmonger has had to work for and is working to mold in his own 
vision. Some viewers commented, "I fist-pumped in the silent, dark theater when he was laying out his plans" (Obie) and others felt the connection of an "individual who has been torn away from their culture" (Sparkles) because Killmonger's history parallels these negative experiences in the real world.

Despite Killmonger's moral centrality, he is taken down by the "rightful" king and is dethroned in an appropriately Marvel-esque battle. T'Challa, the Black Panther, gives the final blow with a choreographed blade to the chest and in that moment, Disney's Marvel perpetuates death as the necessary end for black progress. Coogler and audiences can no longer develop a possible relationship or reparation between T'Challa and Killmonger as Wakandan kin. Instead, the Marvel formula demands a climactic battle of good and evil the hero has to win. One is reminded that the story is still confined to the comic realm and its ultimate journey of the brave protagonist. But as others point out, just because T'Challa can "choose love when Killmonger is consumed with vengeance isn't so much a testament to [his] character as it is an indictment of Wakanda" (Obie). When T'Challa learns of his cousin's tragic past, he morally confronts his father's decision and admits the wrongdoing of his people's past but does not necessarily side with Killmonger. He sadly tells his father, "he is a monster of our own making" and that he must reassume the throne to restore peace to Wakanda. But this peaceful intention perpetuates the lifelong violence and trauma against Killmonger as he rejects Black Panther's condolences and says, "Just bury me in the ocean with my ancestors that jumped from the ships. Because they knew death was better than bondage." This statement identifies Killmonger with the "trauma of the trans-Atlantic slave trade" (Karam 6) and instills that he will always be a stranger to Wakanda and an ancestral line of imperialism. But this reduces his story to being left to die in a homeland that never accepted him and heroically closes the narrative arc of Black Panther. T'Challa 
assumes the king-ly responsibility he has avoided the whole movie and begins to open Wakanda to the world (Killmonger's very intention) and in Oakland (a space of reparations). Good cannot be done on principle by the villain and Jordan's character dies never knowing this has been established. It prioritizes T'Challa's maturation while Killmonger's ending aligns with precontemporary hip-hop films that "rarely had the opportunity or expectation of adulthood (because of premature death)" (Boylorn 148). And instead, the audience champions the future put forth by Black Panther and not the man who sought it in the first place. This leaves an unfulfilled hole of progressive black masculinity in comic spaces and the "fluid, feminist, and resist[ance] [to the]...traditional patriarchy" (Boylorn 148) that black men could believe in is lost because Disney Marvel cannot afford to stray from the hero that drives the money.

The second point many have commented on and criticized is the tribalistic themes of the film. Black Panther was an explicitly black project and held deserved respect as a cultural milestone, but it faltered in certain areas. Black Panther's source material is based in an Africanhidden country (i.e. it never experiences colonization) and free from the oppressive history of Western imperialism. But this does not mean it is free from all traces of colonialism (even Killmonger himself wanted to conquer the ancient civilization). In "Black Panther and the Persistence of the Colonial Gaze," Paul Tiyambe Zeleza notes the "Eurocentric stereotypes...[of] ferocious and bloody fights...Tarzanian animalistic chants... and the poor attention paid to African languages" that creates a homogeneous image of Africa that is "dangerously [too] simplistic" and fails to show the wide diaspora. Historically, Africa has been depicted through the dominant Eurocentric viewpoint. The New Yorker's Jelani Cobb states, "'Africa'-is a creation of a white world and the literary, academic, cinematic, and political mechanisms that it used to give mythology the credibility of truth." Black Panther opens on the fantastical creation story of 
Wakanda and the awesome powers of vibranium that add another mythical spectacle to Marvel. Wakanda is another super imagining that aims at making its culture believable and tangible. This is Africa in the Marvel Cinematic Universe. No one can deny the history of colonialism and its traces in the media. But Zeleza sees this movie as perpetuating the tendency to regard "Africa as the black continent...the habitus of the Negro" and that Wakanda has failed to show "the bewildering complexities, contradictions, and diversities of Africa itself” (Zeleza). Of course, Ryan Coogler never intended this negative response and visited Africa previously, partly for research and partly for personal reasons. He told Rolling Stone, "I was very honest about the idea I wanted to explore in this film, which is what it means to be African. That was one of the first things I talked about. And they were completely interested." Coogler's concept of Africa came from what he was told as a child: "In the diaspora, the Africa we tend to hear about is this fantasy place...Because it's hard to tell a child about slavery - it's so dire and so awful that you kind of have to balance it with something. So we get this fairy-tale version of Africa...It becomes," he says, "kind of like Wakanda." Comic book movies by all account are imaginings and fantasy, nevertheless Coogler and Marvel clearly understood the cultural zeitgeist around this production and its expectant audiences (the film made explicit references to the Atlantic slave trade, etc.) who looked to it as a cultural cornerstone. But in critical circles, the fantasy elements and colonialist reductions were inextricably linked, as Wakanda was uncomfortably stereotypical and discredited as "a bygone society of wizened sagely old men sitting under trees spewing maxims" (Gathara). This does not mean Coogler failed at his vision.

In her book, Critical Race Theory, Alessandra Raengo states,

"Minority artists are burdened with the obligation to act as a proxy for a larger group... Kobena Mercer has described this accumulation of demands as the burden of representation, a situation that expresses the pernicious encroachment of identity politics into the aesthetic assessment of minority art... On one hand, it appears to want to 
consolidate some essential notion of blackness or black people (or a black way of doing scholarship, or a definitively clear concept of what makes a black film, and so on). On the other hand, it appears highly flexible and fluctuating and, therefore, seemingly in need of some form of essentialization" (63)

As the first black superhero, Coogler took on a burdensome job. Representation is powerful and the portrayal of people of color (POC) has often been racist (I struggle to find positive representations of myself in media). Black Panther offered a powerful and positive story. Perhaps this "pernicious encroachment of identity politics" cannot be helped because the few times POC sees themselves on screen, there is a pride to witness your experience as mainstream content. But Coogler's aim to explore African identity can be very personal and different for everyone. He ambitiously fueled a vision through his experiences that are not all universal. One cannot speak to an entire diaspora (nor should they be expected to) as Africa is a culturally and ethnically diverse continent. This Africa is crafted from Coogler's own (deeply personal) experience that cannot act as the universally accepted "Africa". It can be accepted as artistic license (it is fantasy) but the external cultural symbolism of Wakanda played into this burden of representation and built a perception of the real Africa that was expected. Through Killmonger, Coogler was able to discuss life in urban America and the pain associated with ancestral slavery. It was a specific case study, but conversely was able to relate to open discussions of racism, belonging, and homeland that did not get enough screen time to truly facilitate a whole discussion.

Raengo suggests that:

"In film and media studies, this conflation of the political and aesthetic valences of representation has emerged in the form of a reliance on realist aesthetics to communicate the true black experience. This means that, alongside being representative, the artist is also expected to be representational... straightforwardly mimetic... Or, seen from the opposite side, the work is expected to be mimetically reflective of an artist's identity" (64). 
Coogler does not embody all that is Black Panther. He has been given an opportunity to communicate a story that comes from a personal place but is not the sole author of the black experience. He is working within a fantasy genre that is meant to be aspirational and empowering: a black superhero celebrating the leaps of Afrofuturism and seeing a society grow from past trauma. This is not a reflection of realist aesthetics but is constructed as a "retelling/reimagining [of] their futures and revisiting or reimagining their past" (Karam 6). It gives agency to black storytellers like Coogler to establish Wakanda as a powerful country, free from colonization and at the center of cultural and technological progress. But these insights are unfortunately shrouded by the bigger identity of Marvel. One is so quick to pin this burden on Coogler when in fact, it is Marvel's corporate identity taking over much of the film. One can trace the themes and conversations Coogler has planted in the film, but they feel overshadowed by the formulaic action and battles that detract from the character arcs. Marvel made Killmonger's death necessary despite the possibility of a dialogue around trauma and acceptance. Afrofuturism also recognizes the history and collective struggles of black people as a way to reshape a better, more just world (Karam 6). But how can one celebrate progress when Jordan's character was never given proper closure? Marvel as a corporate entity detracts from Black Panther's powerful potential and undervalues Coogler's direction of the story. This so-called marvelous expansion of the cinematic universe is made ineffective if creators are unable to make their vision and the conservatism ultimately vetoes the dynamism of different voices.

\section{Thor Ragnarök}

Thor: Ragnarok is regarded as one of the more unusual features and used director Taika Waititi's artistic persona as its bestselling point. Predecessors in the Thor franchise had a darker, 
more theatrical tone, but Marvel wanted to brighten Thor and send the Norse god on a funny cosmic adventure. Waititi is an indigenous filmmaker from New Zealand known for his whimsical stories, What We Do In The Shadows (2014), Boy (2010), and Hunt For the Wilderpeople (2016) that are infused with quirky humor, heartfelt moments and the lives of indigenous people. Waititi states, "I fully support the idea of getting indigenous people to tell their stories." He described Boy as a "very human story but told in a very unique place" (TIFF) and "the voice given to his characters is distinctly Maori" (Mercier 40). This does not mean Waititi cinematically represents all of Maori culture (like Coogler), but rather draws from his own experiences and aims to "tell a normal story about normal people who happen to be brown" (TIFF). Marvel clearly acknowledged his creative talent in the hiring process. Thor:Ragnarok earned $\$ 854$ million at the theaters, proving its financial payoff to the studio, but not with certain critics. Initially, the press buzzed with surprise when Waititi was announced to take the helm of the next Marvel saga. A New York Times headline read "The Superweirdo Behind 'Thor: Ragnarok," in an interview that showcased Waititi as if Marvel had stumbled upon the next big thing. But Dan Kois, who conducted the interview acknowledges the Disney machine, describing Waititi's hiring as "neatly [fitting the] mold of a lively director plucked from [cozy] indiedom and placed at the center of a franchise," showing an apparent [and relatable] anxiety for him and others as "he's working inside a system expressly designed to have megamovie training wheels" (NYT). Even the article's title side sweeps Waititi's artistic depth and background in New Zealand and markets the "fun" side of the director. From the discussion and evidence of Black Panther, this worry is valid. Ragnarök did not deal with as serious of themes as did Coogler's films and fell flat overall as a narrative. The vibrancy of Waititi's characters are lost in Ragnarök 
(despite the film's psychedelic backdrop and punchy jokes) and lack the emotional development usually seen in his work.

Waititi allows his characters to be fallible, unlikeable, and finds a trace of humanity in them that one can identify with and relate to. It is a prolonged study that plays to his storytelling strengths and ability to construct a dynamic character. But Marvel dares not to shy away from the impenetrable, masculine force and is left with an unsympathetic hero, like Thor. Thor is given multiple obstacles in the duration of the film, but they are physical forms that present no real threat of danger or opportunity for narrative development. The concept of the superhero is grounded in un-human qualities of strength and [often hypermasculine] power that allows for them to become an infallible yet boring being; this constant state of unattainability is "a power fantasy attempting to purge the anxiety about the state of masculinity" (De Dauw 13) and reassure a manly sensibility. If Marvel is supposedly unprecedentedly "blending continuity and renewal" (HBR), the three-act structure is a detriment to character development typical of Waititi's work. The anticipation for a final Marvel battle streamlines the story in the name of the reigning hero and sets up the expectation for an unsurprising victory. To highlight this dichotomy between Waititi's previous style and his work for Disney, I will compare his 2010 film, Boy that discusses male fragility to Thor's multiple "obstacles".

Boy revolves around a young indigenous boy's imaginings of his absentee father. The boy's idolization creates macho personas for his father, as Waititi (who plays Alamein) takes the form of a swash-buckling pirate, karate master, and other roles in his daydreams. When Alamein suddenly arrives, the two play off each other's expectations as Waititi "encourage[s], these eulogistic fantasies in order to impress his son... with Boy progressively taking to imitating the loutish gang-behavior of Alamein" (Fox 196). This dynamic is centered around pleasing the 
other and appeasing the fantasies of fatherhood and family legacy, essentially being each other's heroes. But the veil of appearances eventually disappears when Boy discovers why his father has really returned. Unlike the Marvel Universe, one's everyday heroes can reveal themselves to be just as broken, seeking a similar form of "emotional refuge... [and to find] some power to control a world that has hurt [them] so badly" (Fox 198). Alamein's shattered illusion as a fun-loving father has been replaced with a drunken, desperate man scrambling to finance his gang and reconciling with the trauma of their dead mother. The comedy of the fantasy acting is no longer child's play but a mask for the unresolved grief of father and son. It comes to a climax when Boy slaps his father, angrily shouting “I don't remember you...you weren't there when he was born, you weren't there when she died, where were you?" The emotional weight of the scene offers a release of grief and frustration for Boy but also ends the positive father-son dynamic. As Boy is leaving the shed, he tells Alamein, "I thought I was like you-but I'm not", showing "recognition of this betrayal" against his own long-held expectations of a good father (Fox 197). The last reverse shot shows Alamein slumped at the base of his grand chair. This physical dethronement strips him of his status as a leader and grounds his character outside of his son's imagination. The movie does not excuse Alamein's behaviors, nor does it give him a chance to quickly redeem his past actions (like any hero adventure would) and be the "better man." Waititi does not entertain a happy ending. The last image of the boys and Alamein at the tombstone presents a chance for healing but not necessarily a resolution. The ambiguity of the ending feels natural compared to a convenient resolution. The flawed relationship conveys "at a psychological level, the dynamics of the coming-of age experience...[that] are recognizable to people" as universal trauma and "emotional deprivation" (Fox 192). 
Within the first twenty minutes of Ragnarök, Thor's hammer is destroyed by his sister Hela. The ease in which Hela breaks Mjolnir suggests an unprecedented imbalance of power. Mjolnir acts as an extension of Thor's strength and an affirmation of his worthiness as a god, thus its destruction calls into question his true power as the god of thunder. The crack in his hubris is furthered when Hela teasingly says, "darling, you have no idea what's possible" and proceeds to shatter the hammer with a thunderous blow. Loki realizes the present threat in front of the brothers and pleads to be sent back into the cosmic wormhole. Thor objects, showing a resistance to backing down and attempting to reinforce his presence as a legitimate threat. As Loki is willingly taken by the beam, his brother charges forth, ready to take the goddess of death without Mjolnir. The action can be read as fearlessness but more so a conscious objection. Hela has broken the confines and "constraints of patriarchal hegemonic masculinity" (De Dauw 12) within the family and declared herself ruler of Asgard. It upsets the power balance with Thor now demoted as the inferior being. Yet before he has the chance to confront Hela, the two are derailed and sent to the colorful planet of Sakaar. The plot fuels Thor's anger to return back to Asgard but more importantly, the battle royale with Hulk. Mjolnir's importance suddenly disappears when it comes down to a battle of heightened brute force. The "ever-critical public eye has now been cast onto male bodies" as the computer effects make sure to emphasize the opponents protruding biceps and an overall "exaggerated musculature" (De Dauw 12). When the two go head to head, there is a clear display of animalistic violence and showmanship of strength as the crowd raucously cheers for the Hulk to pummel the puny Thor. Often, "men are socialized to believe that worthiness stems from competition; thus, to be worthy is to be a victorious competitor" (Germaine). The battle allows not only for an exhibition of masculinity but quickly allows Thor to regain his powers. The space between this moment and the hammer scene is but 
maybe twenty minutes. Again, the Marvel hero cannot be without power and control. Thor is not allowed to be weak. One of Hulk's punches conveniently awakens Thor's ability to produce lightning and the god of thunder reclaims this unstoppable force (though it is arguable if he ever lost it) as he catapults Hulk across the arena. There is a renewed sense of energy in the crowd as the stadium switches sides and cheers "Thunder." His victory is denied only by the grandmaster's worry, reinforces Thor as the super being, and voids Mjolnir as a legitimate obstacle in the hero's journey.

Boy accepts the idea of a fragile masculinity. Alamein is hypothetically a great man, who possesses charisma and physical strength that Boy has told everyone else of. But when his gang gets beat up at the bar, he is physically overshadowed and mentally thrown off his confidence. Boy imagines the fight before it happens. The brawl transforms into a choreographed sword duel as Alamein and the other man join arms and spin around as an onlooking crowd chant them on. The idea is theatrical with Waititi wielding the larger machete and bestows confidence in Alamein as a father and protector. But the scenario quickly cuts to reality as Boy's smile fades to see the men throw beer glasses and punches at his father's gang. Unlike the "masculine bodies most male superheroes possess" (De Dauw 12), his father is not an indestructible man and the drive home is a defeated party with battered, bruised, and bloody faces. Alamein tries to rally the gang to keep his own morale high but is met with silence and negativity. It pushes him over the edge as he proclaims, "I'm all alone on this planet...everybody blaming me for some shit", revealing his own internal frustrations. "In a social context, masculinity conflicts with loss, grief, and depression: men are typically exposed to the masculine notion of fighting for what they want and regaining that which they lost" (Germaine). But Alamein has essentially lost everything and cannot grapple with the notion that he has remained un-victorious. He ends up killing Boy's pet 
goat and consoles Boy with a false promise to take him to a Michael Jackson concert as a means to get him back in the car. There is no glimmer of excitement at the offer to see his pop idol, just silent mourning over his dead friend. It marks a change in the emotional tone of the film as Boy no longer idolizes his father. The sense of enchantment begins to unravel. Compared to the scenes described above, Thor does not necessarily align with a director whose stories are rooted in human emotions, trauma, and the acceptance of making mistakes. According to Waititi, Alamein's gang is created out of this "real phenomenon which is the displacement and disenfranchisement of other cultures that have got no other choices but to just start clubs or hang out with people like them ...you know, the Maori have had a pretty rough time over the last 160 years"” (Fox 195). These social bonds are an attempt to fill the hole left by his wife and find control over his situation in life. His world has fallen apart and has no idea how to put it back together.

By contrast, Thor is always given agency over the situation as he quickly recruits a gang to escape Sakaar and challenge Hela. Sakaar is merely an intermission on the journey for revenge against his sister. Once back in Asgard, Hela enters the throne room to see her brother sitting on the golden chair. The positioning of the shot asserts Thor's comfort on the throne as the reigning king of Asgard (vs. Alamein's position on the ground) and the assumption that he will always be above Hela. He taunts back this time, greeting her with a sarcastic and un-endearing "sister." The two go back and forth until it is time for an impending battle. Although this one is different. Compared to the exhibition style of his match with the Hulk, Thor seems to have met his match. Each strike of his seems to be anticipated by Hela and counterstriked with equal, if not more, intensity than his last blow. Hela again presents a legitimate threat against Thor's power as a god and the realm of masculinity. Asgard has historically been ruled by men, yet she aided in the 
rampage that created the golden kingdom. When the mural is shattered and the conquest of Asgard is revealed, the paintings show a bloodthirsty ambition that was recognized as dangerous and consequently banished. Her power as the goddess of death is formidable, mockingly telling Thor, "to be honest, I expected more." She continues to throw her brother around the room with ease and strikes the god of thunder to his knees, delivering the final blow to his eye. Mjolnir was an extension of his physical power but this has debilitated him. He even pleads to his father, “she's too strong, without my hammer, I can't." This is the first admission of Mjolnir's powers since its destruction and for the first time, Thor admits his vulnerability. Hela seems to be the more powerful one in this situation with her stronghold over Asgard. For a split second, it presents a situation where Thor cannot compensate in any means of physical strength or masculine energy. This "symbolic emasculation and disempowerment" (Germaine) could be a developmental moment for Waititi's direction, a chance to reassess the superhero character and its qualities. But Marvel would never allow the structure of the profitable narrative to be tampered with. I acknowledge that comic movies are fantasy and a form of escapism, but again the idea that Marvel is constantly evolving and playing to creatives' strengths has not appeared to be the case. Odin suddenly appears as the proverbial wise man to instill some wisdom upon his son. The advice is somewhat shallow, only reaffirming that his son is "stronger" than his daughter and even himself. It strokes the "dominant masculine ideal" (De Dauw 11) of the superhero and confirms that nothing can stop the arc of the victorious god of thunder.

Instead, Thor's lightning reignites and flies from the castle walls to the skybridge. The electrifying bolts are emphasized a thousand times bigger and slowed down to show them wrapping around his enlarged biceps. The action of the scene entertains the comic enthusiast's fantasies of "epic fights, fancy elocution, and special effects" (NYT). He is able to blast away the 
faceless villains with such ease and given a fighting anthem as his other comrades also face off with undead armies, a giant wolf and a hell monster. When it appears Hela is unstoppable, Thor takes the brave and sacrificial stance to destroy Asgard once and for all. The choice plays up the drama of the situation but also services the "dutiful and familiar" (VF) comic plot and that is more predicable than dynamic. It acknowledges Hela's daunting power but prioritizes her brother's martyrdom to his kingdom. Marvel's hero is predicated on the final showdown between good and evil in which Asgard happens to the prophetic hellfire of it all. Thor is regaled as the hero and supposedly saves the day from another evil. But the victory feels undeserved. A particular review from Vanity Fair's Richard Lawson carries a sigh of disappointment, wishing "instead of feeling glad that he'd been hired to direct the movie, I felt a little sad that he had to bother at all." The movie certainly delivers on the punches and battles (just like Coogler's duties to Black Panther) but Lawson points to the critical predicament I have been arguing from the start:

"Meaning: hopefully, Ragnarok will be a big hit and will write Waititi a blank check to do whatever flight of prickly whimsy he wants to do next. For that, it was probably all worth it. But watching Ragnarok, I was struck by the assimilating, Borg-esque aspect of this whole Marvel enterprise - the way it absorbs filmmakers' talents, compacting them all into the house style. It's almost aggressive from that angle, how they seek out interesting directors and make them bend to their will. At least Ragnarok features what looks a little bit like revolution" (Vanity Fair).

Thor's actions have not necessarily redeemed him or proved him worthy as the savior of Asgard. Even the comics achieved more. Alison Germaine's article, "Disability and Depression in Thor Comic Books" highlights that the "convergence of comics and disability creates a prism through which disabilities can be seen as empowering" in the actual Thor comics and argues against the notion that "disability hinders power and should be "corrected"” (1). Germaine explains the pillars of Thor's character as a traditionally muscular god that becomes synonymous 
with masculinity itself. Like my arguments above, his worthiness stems from physical competition, a masculine image, and dominance of power. But the comics play with this image as there are several moments when Thor loses Mjolnir, a limb, and struggles with depression. It removes these traditional ideals and images, and one is able to see Thor frustrated with the inabilities of his own body. Living as a supernatural being, this is the first time he has been physically and emotionally stunted in a very human way. As the direct source material for Marvel, Waititi could have brilliantly woven in these storylines and built a Thor that could illicit empathy: “ Superheroes and superheroines symbolize strength, courage, and invincibility; hence, the idea of these brave warriors battling disability, depression, and disease creates an element of identification and encouragement..." (Germaine). Their humanity is their greatest strength and Waititi potentially could give an even greater twist to the Marvel masculinity. Instead, the audience is left with a solemnly heroic Thor guiding his fellow Asgardians to a new future.

Thor: Ragnarök delivered on a livelier vision than the previous iterations and was infused with Waititi's whimsical theatrics (as showcased in Boy's daydreams) but was overshadowed by Thor's hulking masculine figure. Black Panther took on complex ideas of colonialism and race that made its way into discussions and was able to be seen and heard onscreen. Thor hinted at the chance to contest ideas of male invulnerability but each situation was too easily overcome and made the story narratively just as dull as its predecessors. Like Coogler, this is not Waititi's fault because they are working within a corporate structure that favors a safe, reliable mediascape that is only motivated by profits and standardized content. It leaves in its wake a space of hollowness and those who have a voice are lost in a capitalist environment that facilitates this corporate behavior.

Closing analysis: 
In their 2019 annual report, Disney boasted a total revenue of “\$69.6 billion” dollars, up “ $17 \%$, or 10.1 billion” dollars from the previous year. The amount is not only staggering but conceptualizes how fast this company will continue to grow. Since Eisner's reign in the eighties, the Walt Disney Company has strategized and sophisticated corporate synergy to aid in its mission of unprecedented media domination. Money is power and sways the voices of Hollywood. This much control is dangerous, and I believe limits the media audiences can experience. Our consumerist economy has signaled the need to adjust entertainment at the same palatable level for everyone. Disney's indoctrination often starts in childhood (when Disney equates to innocence) and seems to last throughout adulthood where their expendable income feeds into the profits of the company. This does not mean viewers are completely unaware, more so, they have less of choice in a shrinking marketplace and have slowly been conditioned to identify with the big brands.

And the company's success is not stopping as it keeps looking for new talent. There have been multiple reports of more directors like Coogler and Waititi enlisting in the Marvel Cinematic Universe, but it seems at the expense of their time. I am not stating Taika Waititi and Ryan Coogler's association with Marvel is wholly negative. It gives them bigger exposure for others to find and appreciate their work as well as move on to more promising projects. But the potential of these projects is sadly lost in their execution under a mega company like Disney/Marvel. They could be great emblems of progress and add depth to a franchise that has been criticized for being "theme park-esque." Black Panther could have been a space for a positive, powerful black future for all its characters, a space where trauma and reconciliation could exist instead of killing them in a "poetic" sunrise. Thor Ragnarök could have explored male vulnerability and the hero's weakness. But one is treated to two hours of patriarchal 
reinforcement that male value is rooted in physical power. Instead these films fall in line with the same beats of CGI explosions and action sequences that draw in the excitement and money for audiences. They will walk away making a good superhero movie, but one has to question, "whether or not we could imagine a global media structure not operating under Disney and, by extension, Anglo-American definitions of what is possible in storytelling” (Anjirbag 167).

These stories rely on the outdated binary of good and evil. But audiences are still enchanted by the escapism of a comic world where heroes and villains face off with punches and explosions, offering the complacency that all we need is the fantasy of the triumphant and undefeated male superhero. A fantasy where one cannot question the fallacies of heroes and even villains. As these movies keep swallowing creatives under the promise of big opportunities, they will continue to be censored under these guidelines because it makes money and maintains Disney's ultimate control. The directors' authorial voice is so strong in their past work and makes the stories impressionable long after viewing. Boy (2010) and Fruitvale Station (2013) introduce and leave questions of politics, race, colonialism, and masculinity. Marvel is made to break the initial box office weekend, but its plots feel less than memorable. Disney has economically crippled the rest of the industry but left the mediascape with the same taste of mediocre plot, static characters, and un-exhilarating battle finales.

As the company is reorganizing its strategies during the pandemic, it has poured its resources into the streaming world and attempted to make all its profits from Hulu and Disney+. With an increased streaming consumption, who is to say if Disney will come out on top as they move their standardized content to household screens. But they are closer to audiences than ever before. As people turn to the comfort of their screens, Disney will continue to produce content (with new creators) for its millions of faithful subscribers with the touch of a button. Either way, 
they will not be unshaken in the immediate future. This new dimension should be taken into careful consideration as Disney continues to expand their portfolio upon a digital era Hollywood.

Notes: Special thanks to Dr. Kristin Hole and Dr. Jungmin Kwon for their patience, feedback and dedication to this thesis.

Works cited

Abele, Robert. "The DGA Interview: Family Dynamic ." Directors Guild of America, DGA, 2019, www.dga.org/Craft/DGAQ/All-Articles/1902-Spring-2019/DGA-Interview-JoeRusso-Anthony-Russo.aspx.

Anjirbag, Michelle Anya. "Reforming Borders of the Imagination: Diversity, Adaptation, Transmediation and Incorporation in the Global Disney Film Landscape.” Jeunesse: Young People, Texts, Cultures, vol. 11 no. 2, 2019, p. 151-176. Project MUSE

Barco, Mandalit del. "Marvel Studios' Kevin Feige On The Future Of Marvel Movies.” NPR, NPR, 26 Apr. 2018, www.npr.org/2018/04/26/605648453/marvel-studios-kevin-feige-onthe-future-of-marvel-movies.

Bohas, Alexandre. "Transnational Firms and the Knowledge Structure: The Case of the Walt Disney Company." Global Society, vol. 29, no. 1, 2014, pp. 23-41., doi:10.1080/13600826.2014.961126. 
Boylorn, Robin M. "From Boys to Men: Hip-Hop, Hood Films, and the Performance of Contemporary Black Masculinity.” Black Camera, vol. 8, no. 2, 2017, p. 146-164. Project MUSE

Burt, Andrew, T. “A New Jack Cop in a New Jack City: New Black Realism and Conceptions of the 'Bad Man.'” Journal of Popular Culture, vol. 52, no. 4, 2019, pp. 931-948.

Calandro, Jr., J. (2019), "M\&A deal-making: Disney, Marvel and the value of "hidden assets"", Strategy and Leadership, Vol. 47 No. 3, pp. 34-39. https://doiorg.proxy.lib.pdx.edu/10.1108/SL-02-2019-0023

Carlsen, Arne, et al. "Marvel's Blockbuster Machine.” Harvard Business Review, 13 Feb. 2020, hbr.org/2019/07/marvels-blockbuster-machine.

Cieply, Michael, and Brooks Barnes. “Disney Sells Miramax for \$660 Million.” The New York Times, The New York Times, 30 July 2010, www.nytimes.com/2010/07/31/business/media/31miramax.html.

Cobb, Jelani. “"Black Panther' and the Invention of 'Africa.”" The New Yorker, The New Yorker , 18 Feb. 2018, www.newyorker.com/news/daily-comment/black-panther-and-theinvention-of-africa.

Dargis, Manohla. 'Review: 'Thor: Ragnarok,' of Gods, Monsters and Silly Jokes (Published 2017)." The New York Times, The New York Times, 1 Nov. 2017, www.nytimes.com/2017/11/01/movies/thor-ragnarok-review-chris-hemsworth.html/.

De Dauw, Esther. “The Masculinity of American Superheroes.” Frontier, University of Leicester , 2017, journals.le.ac.uk/ojs1/index.php/frontier/article/view/3181. 
“Disenyization.” The Disneyization of Society, by Alan Bryman, SAGE, 2004, pp. 8-20.

Ebert, Roger. “Iron Man.” Roger Ebert, Roger Ebert , 1 June 2008, www.rogerebert.com/reviews/iron-man-2008.

Ebert, Roger. "The Westminster Dog Show of Superheroes." Roger Ebert, Roger Ebert , 2 May 2012, www.rogerebert.com/reviews/the-avengers-2012.

Eells, Josh. "Ryan Coogler: Why I Needed to Make 'Black Panther'." Rolling Stone, Rolling Stone, 25 June 2018, www.rollingstone.com/movies/movie-features/ryan-coogler-why-ineeded-to-make-black-panther-203737/.

Flanagan, Martin, et al. The Marvel Studios Phenomenon. Bloomsbury Academic \& Professional, 2017.

Gathara, Patrick. "Opinion | 'Black Panther' Offers a Regressive, Neocolonial Vision of Africa.” The Washington Post, WP Company, 1 Apr. 2019, www.washingtonpost.com/news/globalopinions/wp/2018/02/26/black-panther-offers-a-regressive-neocolonial-vision-of-africa/.

Germaine, Alison Elizabeth. "Disability and Depression in Thor Comic Books." Disability Studies Quarterly, vol. 36, no. 3, 2016, doi:10.18061/dsq.v36i3.5015.

“Golden Era Redux." Empires of Entertainment: Media Industries and the Politics of Deregulation, 1980-1996, by Jennifer Holt, Rutgers U.P., 2011, pp. 93-114. 
Grob, Marco. "Marvel Studios: the first ten years." Variety. 8, February 2018, https://variety.com/2018/film/news/marvel-class-photo-10th-anniversary-celebration$\underline{1202692301 /}$

Johnson, Derek. "Cinematic Destiny: Marvel Studios and the Trade Stories of Industrial Convergence." Cinema Journal, vol. 52, no. 1, 2012, pp. 1-24., www.jstor.org/stable/23360278.

Karam, Beschara, and Mark Kirby-Hirst. "Guest Editorial for Themed Section Black Panther and Afrofuturism: Theoretical Discourse and Review.” Image \& Text, no. 33, 2019, doi:10.17159/2617-3255/2018/n33a1.

Kois, Dan. “The Superweirdo Behind 'Thor: Ragnarok'.” The New York Times, The New York Times, 19 Oct. 2017, www.nytimes.com/2017/10/19/magazine/the-superweirdo-behindthor-ragnarok.html.

Lawson, Richard. "Thor: Ragnarok Review: Taika Waititi Almost Transcends the MarvelVerse.” Vanity Fair, Vanity Fair, 25 Oct. 2017, www.vanityfair.com/hollywood/2017/10/thor-ragnarok-review-marvel-chris-hemsworthtaika-waititi.

Mercier, O.. Close Encounters of the Māori Kind - Talking Interaction in the Films of Taika Waititi. 1, Open Access Victoria University of Wellington | Te Herenga Waka, 1 Jan. 2007, doi:10.26686/wgtn.12981110.v1. 
Newman, Michael Z. "Indie Culture: In Pursuit of the Authentic Autonomous Alternative." Cinema Journal, vol. 48, no. 3, 2009, pp. 16-34. JSTOR, www.jstor.org/stable/20484466. Accessed 10 Nov. 2020.

Obie, Brooke. "In Defense Of Erik Killmonger And The Forgotten Children Of Wakanda." SHADOW\&ACT Home, 17 Feb. 2018, shadowandact.com/erik-killmonger-forgottenwakanda.

Originals, TIFF. Taika Waititi on Creating Authentic Indigenous Stories-TIFF 2019. TIFF Originals , 13 Feb. 2019, www.youtube.com/watch?v=a9PxD7eDhFs.

Owczarski, Kimberly A. (2015) "More Than Meets the Eye": Transformers and the Complexities of Franchise Film Production in Contemporary Hollywood, Quarterly Review of Film and Video, 32:8, 675-694, DOI: 10.1080/10509208.2015.1078274

"Parental Abandonment and the Trauma of Loss: Boy (Taika Waititi, 2010)." Coming-of-Age Cinema in New Zealand: Genre, Gender and Adaptation in a National Cinema, by Alistair Fox, Edinburgh University Press, Edinburgh, 2017, pp. 189-202. JSTOR, www.jstor.org/stable/10.3366/j.ctt1tqxtsn.20. Accessed 30 Oct. 2020

Perren, Alisa. "Sex, Lies and Marketing: Miramax and the Development of the Quality Indie Blockbuster." Film Quarterly, vol. 55, no. 2, 2001, pp. 30-39. JSTOR, www.jstor.org/stable/10.1525/fq.2001.55.2.30.

Raengo, Alessandra. "Critical Race Theory." Critical Race Theory and Bamboozled. London: Bloomsbury Academic, 2016. 15-98. Screen Studies. Web. 29 Oct. 2020. <http://dx.doi.org/10.5040/9781501305825.ch-001>. 
Robinson, Joanna, and Photography by Jason Bell. “An Extended Conversation with Kevin Feige.” Vanity Fair, Vanity Fair, 6 Dec. 2017, www.vanityfair.com/hollywood/2017/12/marvel-kevin-feige-interview.

Ryan, Coogler, director. Black Panther. Walt Disney Pictures, 2019.

Scott, A. O. “A New Year, and a Last Day Alive.” The New York Times, The New York Times, 11 July 2013, www.nytimes.com/2013/07/12/movies/fruitvale-station-is-based-on-thestory-of-oscar-grant-iii.html.

Scott, A. O. "Heavy Suit, Light Touches." The New York Times, The New York Times, 2 May 2008, www.nytimes.com/2008/05/02/movies/02iron.html.

Serwer, Adam. "The Tragedy of Erik Killmonger.” The Atlantic, Atlantic Media Company, 21 Feb. 2018, www.theatlantic.com/entertainment/archive/2018/02/black-panther-erikkillmonger/553805/.

Sparkles, Kira. "Black Panther's Killmonger Represents a Loss of Cultural Identity.” Black Panther Killmonger Represents Losing Cultural Identity| The Mary Sue, 7 Mar. 2018, www.themarysue.com/killmonger-and-cultural-identity/.

Taika, Waititi, director. Thor Ragnarök. Walt Disney Pictures, 2017.

The Walt Disney Company. Annual Report 1999, 1999.

The Walt Disney Company. Fiscal Year 2019 Annual Financial Report 2019, 2019. 
Tiyambe Zeleza, Paul. "Black Panther and the Persistence of the Colonial Gaze." Medium, USIU-Africa, 3 Apr. 2018, medium.com/@USIUAfrica/black-panther-and-the-persistenceof-the-colonial-gaze-6c093fa4156d.

. Tzioumakis, Yannis. "American Independent Cinema in the Age of Convergence", Revue française d'études américaines, vol. 136, no. 2, 2013, pp. 52-66.

Walt Disney Pictures. “Avengers Assemble.” Slant. 18, May 2012, https://www.slantmagazine.com/film/critical-distance-the-avengers/

Wasko, Janet. “The Walt Disney Company.” Global Media Giants, Routledge, 2016, pp. 11-25.

Wasko, Janet. “Challenging Disney Myths.” Journal of Communication Inquiry, vol. 25, no. 3, July 2001, pp. 237-257, doi:10.1177/0196859901025003004.

Wayne, Michael. "Post-Fordism, Monopoly Capitalism, and Hollywood's Media Industrial Complex.” International Journal of Cultural Studies, vol. 6, no. 1, Mar. 2003, pp. 82103, 